\title{
Gastric Neuroendocrine Tumor pN1 TNM Finding v8
}

National Cancer Institute

\section{Source}

National Cancer Institute. Gastric Neuroendocrine Tumor pN1 TNM Finding v8. NCI

Thesaurus. Code C135044.

Gastric neuroendocrine tumor with regional lymph node metastasis. (from AJCC 8th Ed.) 